\title{
The Adsorption Efficiency of Modified Fly Ash for the Removal of Iron and Zinc lons
}

\author{
Mohammed Sulieman Ali Eltoum ${ }^{1, ~ *, ~ S a h l ~ Y a s i n ~}{ }^{2}$ \\ ${ }^{1}$ Chemistry Department, Sudan University of Science and Technology, Khartoum, Sudan \\ ${ }^{2}$ Sudanese Chemical Society, Khartoum, Sudan
}

Email address:

abotrtee174@gmail.com (M. S. A. Eltoum), sahlyasin6@gmail.com (S. Yasin)

*Corresponding author

\section{To cite this article:}

Mohammed Sulieman Ali Eltoum, Sahl Yasin. The Adsorption Efficiency of Modified Fly Ash for the Removal of Iron and Zinc Ions. Modern Chemistry. Vol. 8, No. 1, 2020, pp. 12-17. doi: 10.11648/j.mc.20200801.13

Received: October 21, 2019; Accepted: November 14, 2019; Published: April 13, 2020

\begin{abstract}
The aim of study was to reduce chemical contaminant from water and wastewater by adopting low-cost adsorption process over modified fly ash, which prepared easily by two methods, alkaline added under hydrothermal conditions, some physio-chemical technique used to characterize the modified fly ash as XRF, XRD, BET technique and scanning electron microscopy SEM. The result showed that the modified fly ash has crystal structure hexagonal and it attributed to zeolite A, the regarding of crystal structure, specific surface area and external morphology examined by SEM, the estimation of specific surface area affiliated to type (IIB) isotherm which is similar to non-porous or macroporous materials, finding results showed that the modified fly ash described better to both Freundlich and Langmuir model isotherm for removal mechanism, the maximum adsorption capacity $\mathrm{q}_{\max }$ for $\mathrm{Zn}^{2+}$ an $\mathrm{Fe}^{2+}$ is 114.2 and $196.7 \mathrm{mg} / \mathrm{L}$ respectively, furthermore, iron and zinc ions removed well by direct method SZ1 due to the crystal lattice structure, big surface area and pore size 49.317 and $38.813 \mathrm{~m}^{2} / \mathrm{g}$ respectively, finally modified fly ash can be used as low-cost adsorption material due to the nature of ionexchange and performance in adsorption according to their big surface area.
\end{abstract}

Keywords: Fly Ash, Modified Fly Ash, Adsorption, Isotherm, Marco-porous

\section{Introduction}

Over the coming decades demand for freshwater and energy will be raised due to meet the need of fast increasing growing of population and economies, this will load on limited natural resources. There are many sources to generate electricity power, one of the broad uses is thermal power generation, which using coals, natural gas, oil, fossil fuel and petroleum coke [1].

The power station product coal fly ash CFA during electricity generation at $1200-1700^{\circ} \mathrm{C}$, various compound organic and inorganic identified, Blisset et al investigated that more than 316 individual minerals and 188 mineral group existed in different CFA. [2]. fly ash consider to be byproduct from coal combustion, the landfill of CFA affects the environment especially ground water and surface water, in the other hand the important beneficial is to convert this waste to sustainable material, therefore, in 2012 United
States produced alone 52 million tons of CFA about $45 \%$ of total products of CFA in the world [3], more than $85 \%$ of most fly ashes contain chemical compounds and glasses, the chemical composition rich of metal oxide such as $\mathrm{SiO}_{2}>$ $\mathrm{Al}_{2} \mathrm{O}_{3}>\mathrm{Fe}_{2} \mathrm{O}_{3}>\mathrm{CaO}>\mathrm{MgO}>\mathrm{K}_{2} \mathrm{O}>\mathrm{Na}_{2} \mathrm{O}>\mathrm{TiO}_{2}$, form moderate to high concentrations [2], [4]. Ramezani identified that North America is the first country used fly ash in concrete in early 1937 from that time CFA became a major component to facilitate concrete, however, it can improve the feature of concrete by reducing the carbon footprint [4].

The main constituents in CFA are silica and Alumina which can be converted easily to zeolite by two methods hydrothermal and fusion. Fusion method restricted by speed of reaction, however, the final production depends on some conditions such as suitable range of temperature as well as promoting agent like sodium hydroxide or potassium chloride to enhance the reaction activity by increasing crystalline formation. In last few years fly ash has been used in wild range as raw materials, low cost microporous 
aluminosiliceous as zeolite to remove heavy metals, anions groups, and other metals ions, due to its unique function big surface area, suitable pore size and volume by adopting ion exchange and adsorption technique [5]

The term zeolite received attention in last few years due to unique structure it's highly crystalline alumina-silicate materials $\mathrm{Si}$ and $\mathrm{Al}$ are major components they form $\mathrm{SiO}_{4}$ and $\mathrm{AlO}_{4}$ structure, it can reduce and recovery some element ions from their solutions easy by adsorption and ion exchange technique, however, can be used in catalysis as carrier materials, zeolite A was prepared first in 1954 Pathak achieved that in 2014 [6]. A types of zeolite have been prepared from fly ash such as zeolite type 4A, X type, Y type and MCM-41 [7-9]. It should be noted that, indirect methods haven 't been used in wild range.

Heavy metals have harmful effect in environment and human, the concentration of heavy metals increase due to some industrial especially electronic industries, cooling systems and plating industry, organic wastes and ground water, it exists in water, soil, and air, heavy metals react with cellular structural proteins, enzymes and membrane system, certain metals such as chromium and nickel have been linked with cancers in exposed human populations, whereas heavy metals have some benefit such as zinc deficiency is associated with poor growth and development and impaired immune response also iron it can a bear in anemia [10-12].

Modified fly ash synthesized in the present study by two methods direct and indirect and physiochemical characterization and the efficiency performs to remove $\mathrm{Zn}^{2+}$ and $\mathrm{Fe}^{2+}$ from aqueous solution has been studied

\section{Experimental}

Flay ash collected from Garri electricity station (North Khartoum- Sudan). Fly ash is by- product of thermal electricity power station which consume petroleum cock, Seliman et al estimate the function and the properties of petroleum cock [13].

The XRF analysis estimated chemical composition of the fly ash consists mainly of Silica and Alumina as a major, other metals oxide such as $\mathrm{Fe}_{2} \mathrm{O}_{3}$ and $\mathrm{CaO}$ occurring as minor, the element parentage in fly ash samples was found to be as in Table 1.

Table 1. Fly ash composition.

\begin{tabular}{ll}
\hline Metal oxide & percentage \\
\hline $\mathrm{SiO}_{2}$ & 39.8 \\
$\mathrm{Al}_{2} \mathrm{O}_{3}$ & 25.9 \\
$\mathrm{Fe}_{2} \mathrm{O}_{3}$ & 16.8 \\
$\mathrm{CaO}$ & 1.98 \\
$\mathrm{TiO}_{2}$ & 0.84 \\
Unburnt carbon & 33.24 \\
\hline
\end{tabular}

The collected samples were initially screened to eliminate larger particles and calcined at $800 \pm 10^{\circ} \mathrm{C}$ for $2 \mathrm{~h}$ to remove the unburnt carbon and volatiles. The syntheses of zeolite from fly ash was followed according to the procedure reported by Ruen-ngam et al $[14,9]$, direct methods prepared by added alkali to fly ash under following step. $10 \mathrm{~g}$ of fly ash was added to $10 \mathrm{~g}$ of sodium hydroxide, the mixture was burnt in air at $550^{\circ} \mathrm{C}$ for one hour in furnace, the product was crushed and dissolved in $85 \mathrm{~cm}^{3}$ distilled water then stirred for 25 hours at room temperature, the crystallization started, after placed on autoclave for 2 hours at $90^{\circ} \mathrm{C}$. The final product was washed several times with distilled water until the $\mathrm{pH}$ reached 10 and it was dried over night at $105^{\circ} \mathrm{C}$ labeled as SZ1. While, indirect type of zeolite was prepared by treating fly ash with $2 \mathrm{M}$ sodium hydroxide with $3: 1$ ratio, heated to boil for 2 hours, however, the extract solution neutralized by $1 \mathrm{M} \mathrm{HCl}$, white gel obtained after few minutes, under stirring at room temperature, whereas white gel saved in autoclave for 10 hours, then it washed and calcinated at $600^{\circ} \mathrm{C}$ for 2 hours labeled as SZ2.

\subsection{Characterization and Analysis}

X-ray diffraction XRD used to indicate crystalline as well as purity and structure, the samples were grounded into fine homogenous powder and exposed to X-ray. The wild angle $\mathrm{X}-$ ray scattering of samples was measured by X-ray diffraction (D8 advanced powder diffractometer) with $\mathrm{Cu} \mathrm{K} \alpha$ radiation, the diffraction was collected at $5-90^{\circ}$ with step size of $0.028^{\circ}$, while $\mathrm{CaF}_{2}$ used as internal standard, the technique done by using (Panan analytical X'Pert ${ }^{3}$ MRD (Netherlands)), however, chemical composition of the samples was analyzed by X-ray Fluorescence XRF. On the other hand the specific surface area, pore size, and volume were calculated using the adsorption of data of $\mathrm{N}_{2}$ (adsorption-desorption) analysis by adopting Brunaur, Emmett and Teller (BET) model in the relative pressures range between 0.05 to 0.35 , whereas the distribution of the pores and their average diameter were calculated from the BJH model. In addition the surface area and morphology determined by scan electron microscopy SEM Shematzu Japan, monograph image of aforementioned samples were taken on $500 \mu$ magnification. The concentration of remaining metals determined by atomic absorption spectroscopy using the standard procedure, by (Savanta serial No AA7638GBC (Australia).

\subsection{Physical Properties}

The samples were grounded and sieved in the mesh between 150 to $200 \mu \mathrm{m}$, although the mechanisms of zeolite as cation exchange is participating ion through the internal channels and cavities or their hindered movement through the film of ordered water which exists on the surface of the zeolite. Although to indicate ion exchange capacity of the samples, convert final product (zeolite) to $\mathrm{NH}_{4}$-zeolite by added $0.1 \mathrm{M} \mathrm{NH}_{4} \mathrm{Cl}$ for 2 hours, filtration and determined the concentration of $\mathrm{NH}_{4} \mathrm{Cl}$ in the solution, ion exchange capacity confirmed [15].

\subsection{Adsorption Isotherms}

The equilibrium adsorption of $\mathrm{Fe}^{2+}$ and $\mathrm{Zn}^{2+}$ ions in to modified fly ash carried out by contacting $0.5 \mathrm{~g}$ adsorbent with $50 \mathrm{~cm}^{3}$ ionic solution at different concentration from 100 to 
$500 \mathrm{ppm}$ for 80 minutes in starrier, in constant temperature and $\mathrm{pH}$, the filtrate was analyzed by atomic absorption (AAS), while the amount of adsorbed qe $(\mathrm{mg} / \mathrm{g})$ was calculated by using Vanderborght and Van Griekenn formulation

$$
q_{e}=\frac{\mathrm{v}\left(\mathrm{C}_{0}-\mathrm{Ce}\right)}{\mathrm{m}}
$$

Where $\left(\mathrm{q}_{\mathrm{e}}\right)$ is the metal concentration on the zeolite $(\mathrm{mg} / \mathrm{g})$ at equilibrium, $\left(\mathrm{C}_{\mathrm{e}}\right)$ is metal concentration in solution $\left(\mathrm{mg} / \mathrm{dm}^{3}\right)$ at equilibrium, $\left(\mathrm{C}_{\mathrm{o}}\right)$ is initial metal concentration in solution $\left(\mathrm{mg} / \mathrm{dm}^{3}\right),(\mathrm{V})$ is initial volume of metal solution used $\left(\mathrm{cm}^{3}\right)$, and $(\mathrm{m})$ is mass of zeolite used.

Equilibrium data, commonly known as adsorption isotherms, are a requirement for design an adsorption system, there are many adsorption models such as (Freundlich, Langmuir, and Dubinin- Radushkevch .... etc.).

Freundlich and Langmuir were used to describing the equilibrium between adsorbed metals ions on the samples cell $\left(\mathrm{q}_{\mathrm{e}}\right)$ and metals ions in solution $\left(\mathrm{C}_{\mathrm{e}}\right)$ at a constant temperature. Freundlich model supposes that uptake or adsorption of ions occurs on the heterogeneous surface by monolayer, these data often fit the empirical equation proposed by Freundlich:

$$
q_{e}=K_{f}\left(C_{e}\right)^{\frac{1}{n}}
$$

Where $\mathrm{K}_{\mathrm{f}}$ and $\mathrm{n}$ are constant of Freundlich characteristic of the system used to indicate the capacity and intensity of adsorption.

Equation (1) can be linearized in logarithmic form and the constants can be determined, to find (n) and (k) plot $\log \mathrm{C}_{\mathrm{e}} \mathrm{vs}$ $\log \mathrm{q}_{\mathrm{e}}$.

$$
\log \left(q_{e}\right)=\log K_{f}+\frac{1}{n} \log \left(C_{e}\right)
$$

Where $K_{f}$ and $1 / n$ are Freundlich constant due to adsorption capacity and adsorption intensity respectively, the value $\mathrm{n}$ determine the degree on nonlinearity between adsorption and concentration of the solution as:

$\mathrm{n}=1$ adsorption is linear, $\mathrm{n}<1$ adoption follow the chemical process, $\mathrm{n}>1$ follow the physical process.

Whereas, the Langmuir equation was described the metal ions on homogenous surface adopted by monolayer adsorption is given by Equation (4)

$$
q_{e}=q_{\max } \frac{K_{L} C_{e}}{1+K_{L} C_{e}}
$$

$\mathrm{q}_{\max }\left(\mathrm{mg} \cdot \mathrm{g}^{-1}\right.$ ) is the maximum amount of metal ions per unit weight of solid to form a complete monolayer on the surface-bound

$\mathrm{C}_{\mathrm{e}}=$ the equilibrium concentration of adsorbate $\left(\mathrm{mg} / \mathrm{L}^{-1}\right)$

$\mathrm{q}_{\mathrm{e}}=$ the amount of metals adsorbed per gram at equilibrium (mg.g $\left.{ }^{-1}\right)$

$\mathrm{K}_{\mathrm{L}}=$ Langmuir isotherm constant $\left(\mathrm{L} \cdot \mathrm{mg}^{-1}\right)$

To find Langmuir adsorption parameters transforming the equation (4) into leaner form

$$
\frac{1}{q_{e}}=\frac{1}{q_{\max } K_{L} C_{e}}+\frac{1}{q_{\max }}
$$

The value of $\mathrm{q}_{\max }$ and $\mathrm{K}_{\mathrm{L}}$ were calculated from the slope and intercept directly after the Langmuir plot $1 / \mathrm{C}_{\mathrm{e}}$ vs $1 / \mathrm{q}_{\mathrm{e}}$. [16-18].

\section{Results and Discussions}

\subsection{Physical Properties}

The table shows the main physical properties of SZ1 and SZ, the result shows that SZ1 has a high ion exchange capacity than SZ2 as well as pore volume, pore diameter, and low moisture content.

Table 2. Physical properties of the samples.

\begin{tabular}{lll}
\hline Parameters & SZ1 & SZ2 \\
\hline Cation exchange capacity meq $\mathrm{g}^{-1}$ & 2.4 & 2.03 \\
Particle size $\mu \mathrm{m}$ & $150-200$ & $150-200$ \\
Moisture content $\%$ & 13 & 12 \\
Surface area $\mathrm{m}^{2} / \mathrm{g}$ & 40.317 & 30.813 \\
Volume pore $\mathrm{cm}^{3} \mathrm{~g}^{-1}$ & 0.11 & 0.101 \\
Pore diameter $\mathrm{nm}$ & 1.17 & 1.12 \\
\hline
\end{tabular}

\subsection{Chemical Characterization}

XRD results of the samples indicted the appearance of the crystal grain, the samples composted of quartz and iron oxides which located in the outer surface, the result showed slight different between SZ1 and SZ2 which indicate that both SZ1 and SZ2 points to hexagonal structure and four diffraction peaks were SZ1 observed at $2 \theta=20.77^{\circ}, 26.61^{\circ}$, $36.5^{\circ}$, and $50, \mathrm{SZ} 2$ sample showed characteristic peak at $2 \theta=$ $20.79^{\circ}, 26.59^{\circ}, 36.50^{\circ}$ and $50.11^{\circ}$, while the d-spacing $\mathrm{d}_{\mathrm{hkl}}$ of $\mathrm{SZ} 1$ is $4.27,3.34,2.46$, and $1.82 A$ for SZ2 is $4.27,3.35,2.46$, and $1.820 \AA$. The XRD pattern of the samples shows the pure-form and high crystalline structure, for these perspectives the samples attributed to zeolite A also known as LTA. Another way, fly ash prepared by Fronus et al by controlling the concentration of sodium hydroxide over fly ash, three types of zeolite were observed during synthesis $\mathrm{Na}-\mathrm{X}, \mathrm{Na}-\mathrm{Pi}$ and sodaite $[19,20]$

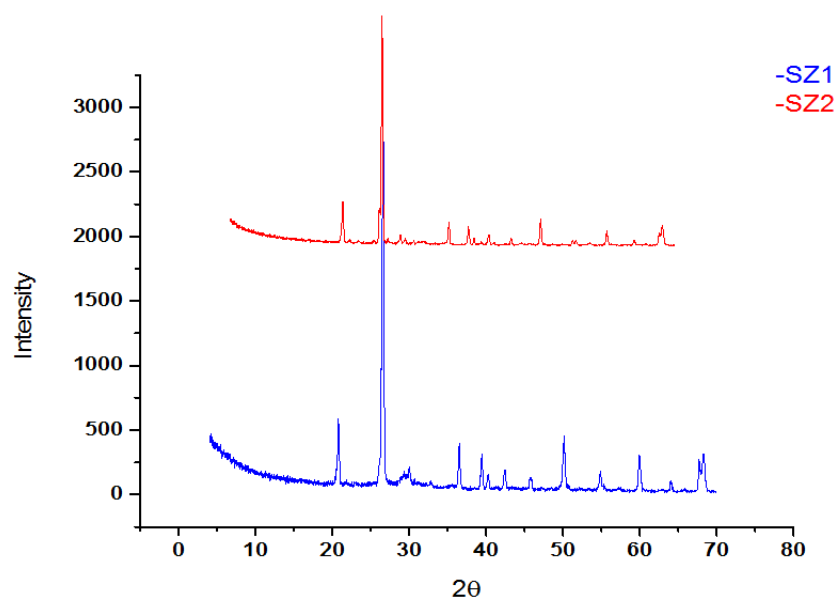

Figure 1. XRD pattern of SZ1 and SZ2. 


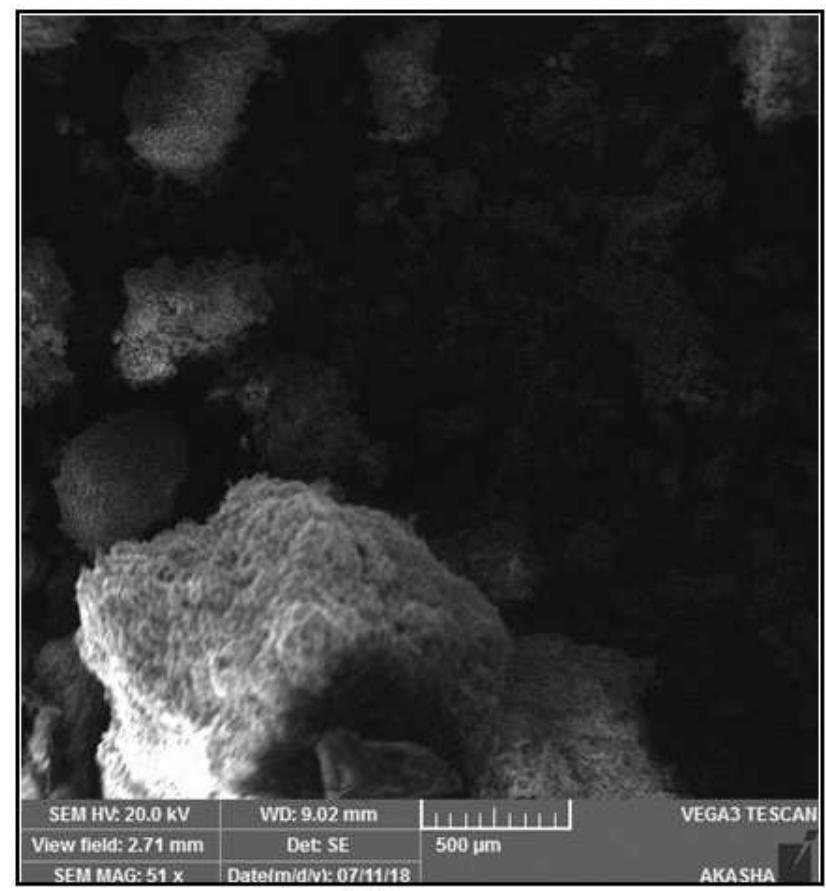

(a)

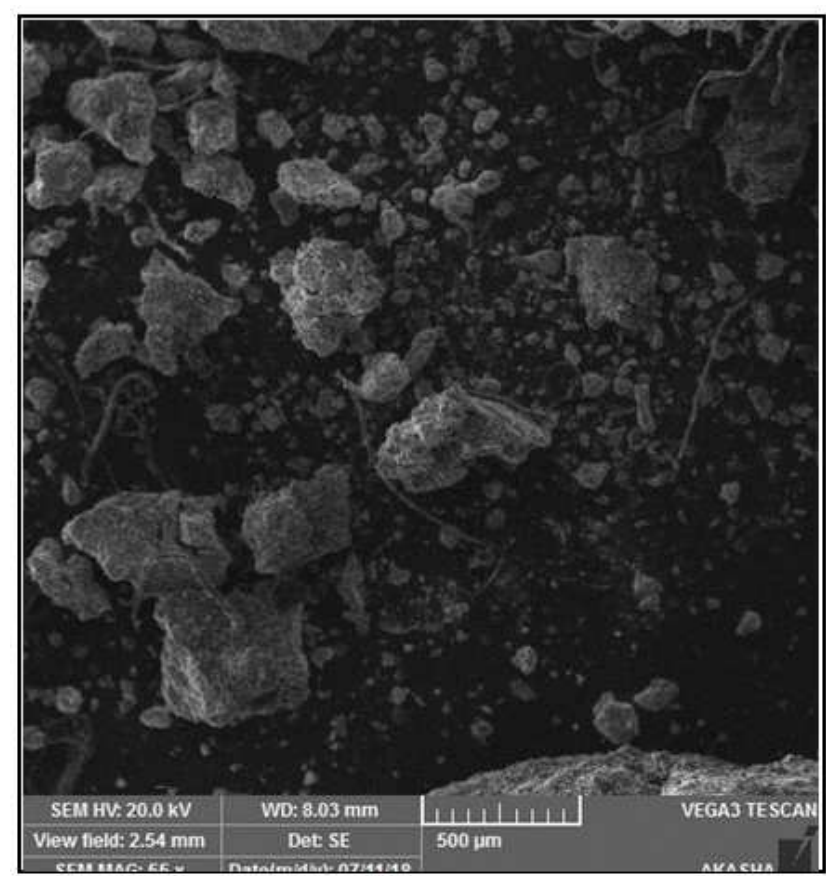

(b)

Figure 2. SEM of SZ1 and SZ2.

The image of aforementioned samples by SEM in Figure 2 $a$ and $b$ revealed that the external morphology, well- defined crystal to both samples, was a hexagonal system, while the image showed external surface area, and the porous clear observed through SEM.

Nitrogen adsorption- desorption isotherm illustrated in Figure 3, however, the BET surface area of the samples 40.317 and $30.813 \mathrm{~m}^{2} \mathrm{~g}^{-1}$ respectively 5 . The BET adsorptiondesorption isotherm and its hysteresis loop give useful information about physisorption mechanism which can predict the pre-type, the samples were classified as type ПВ according to IUPAC classification, and for the samples, there is different of pore size combined. The type ПВ normal for materials with non-porous or macroporous Aluminosilicate adsorbent, however, obtained monolayer and multilayer adsorption mechanism of gas, with an open and stable external surface of the samples. Nevertheless, the presence of the sharp sorption step adsorption start from 0.66 to 0.92 value of $\mathrm{P} / \mathrm{P}_{0}$ revealed that the samples resemble to macroporous. In addition the initial part of this type isotherm attributed to both mono and multilayer adsorption, the samples showed type $\mathrm{H}_{3}$ of adsorption hysteresis loop which doesn't exhibit any limiting adsorption at high $\mathrm{P} / \mathrm{P}_{\circ}$, the shape of the samples resemble zeolite A. [21, 9, 22]

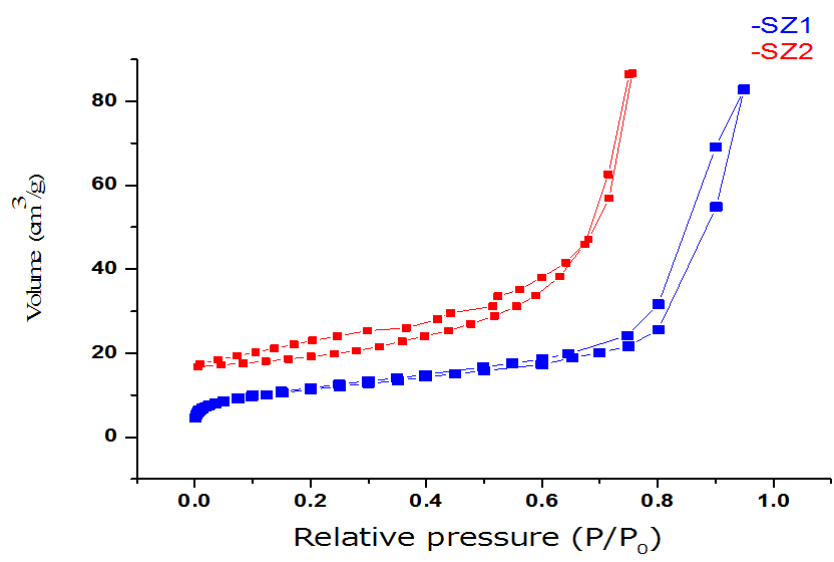

Figure 3. $N_{2}$ adsorption-desorption isotherm of SZ1 and SZ2.

To understanding adsorption process and equilibrium condition, two types of isotherm applied, the isotherm adsorption of $\mathrm{Fe}^{2+}$ and $\mathrm{Zn}^{2+}$ over modified fly ash sieve were illustrated according to Freundlich and Langmuir, which they are most common isotherms for determining adsorption mechanisms process. Since $\mathrm{n}$ value on Freundlich isotherm for $\mathrm{Zn}^{2+}$ and $\mathrm{Fe}^{2+}$ lies $<1$ is favored to fit physical adsorption on the surface of adsorbent where showed in Table 3, although, the value of $\mathrm{n}$, when fallen between 1 to 10 , represent good adsorption, while low value of $n$ describe heterogeneity adsorbed ions on the adsorbent, for both SZ1 and SZ2 $\mathrm{K}_{\mathrm{f}}$ value fit between 0.57 and 1.8 [23]. The monolayer homogenous adsorption capacity saturation at equilibrium represented by Langmuir constant $\mathrm{q}_{\max }$, which for $\mathrm{Zn}^{2+}$ an $\mathrm{Fe}^{2+}$ is 114.2 and $196.7 \mathrm{mg} / \mathrm{L}$ respectively, the other constant $\mathrm{K}_{\mathrm{L}}$ is used to indicate the affinity of ions $\mathrm{Fe}^{2+}$ and $\mathrm{zn}^{2+}$ to adsorbent. The result shown that SZ1 fit well to Freundlich isotherm according to the value of $\mathrm{R}^{2} 0.810$ and 0.928, while, SZ2 plot high Langmuir than Freundlich isotherm due to $R^{2}$ value 0.924 and 0.998 which suggesting homogenous distribution surface, the ions $\mathrm{Zn}^{2+}$ and $\mathrm{Fe}^{2+}$ bent to the adsorbent by chemical bonds. [17, 24], however, the results exanimated the ability of these isotherms to described the process of adsorption in the solution, the parameters, and factors of the isotherms presented in Table 3 below. 
Table 3. Isotherm parameters of SZ1 and SZ2 Freundlich an Langmiur.

\begin{tabular}{lllllllll}
\hline & Ions & $\mathbf{K}_{\mathbf{f}}$ & $\mathbf{n}$ & $\mathbf{R}$ & $\mathbf{q}_{\max \mathbf{m} / \mathbf{g}}$ & $\mathbf{K}_{\mathbf{L} \mathbf{m g} / \mathbf{L}}$ & $\mathbf{R}$ & The equation \\
\hline \multirow{2}{*}{$\mathrm{SZ} 1$} & $\mathrm{Zn}^{2+}$ & 1.8 & 0.78 & 0.810 & 114.2 & 0.05 & 0.874 & $\mathrm{y}=0.6287 \mathrm{x}-0.786 \mathrm{y}=0.0052 \mathrm{x}-1 \mathrm{E}-05$ \\
& $\mathrm{Fe}^{2+}$ & 1.02 & 0.42 & 0.928 & 196.7 & 0.03 & 0.952 & $\mathrm{y}=0.5485 \mathrm{x}-0.4259 \mathrm{y}=0.0079 \mathrm{x}-3 \mathrm{E}-05$ \\
$\mathrm{SZ2}$ & $\mathrm{Zn}^{2+}$ & 1.7 & 1.7 & 0.972 & 0.15 & 0.00 & 0.924 & $\mathrm{y}=-1.4574 \mathrm{x}+1.7011 \mathrm{y}=0.0294 \mathrm{x}-0.001$ \\
& $\mathrm{Fe}^{2+}$ & 0.57 & 0.57 & 0.995 & 0.02 & 0.00 & 0.998 & $\mathrm{y}=0.8431 \mathrm{x}+0.5762 \mathrm{y}=0.2931 \mathrm{x}+0.0069$ \\
\hline
\end{tabular}

*The first equation belong to Freundlich isotherm

\section{Conclusions}

Heavy metal ions such as $\mathrm{Zn}^{2+}, \mathrm{Fe}^{2+}, \mathrm{Cd}^{2+} \ldots$..etc. have a harmful effect on the environment, it transfers into food network, they are persistent toxic in high concentration, and non-biodegradable metal. Through this study it found that treated fly ash by alkali under hydrothermal conditions has capable to enhance its adsorption capacity and therefore its removal efficiency, Zeolites is low-cost materials for water and waste water treatment due to their high ion exchange capacity and high-performance adsorption of cations in aqueous solution. Further understanding the effect of alkali treatment on the surface of fly ash, characteristics and properties of SZ1 and SZ2 were achieved through advanced characterization such as XRF, XRD, SEM, and BET specific surface area. The result shows that modified fly ash has unique structure, and high efficiency to reduce heavy metals from aqueous solutions, the removal equilibrium obey Langmuir isotherm for SZ2 while Freundlich isotherm fit well to SZ1, to sum up, the final product characterized by (XRD, BET method), it have big surface area as well as suitable pore size, it can use for catalysis design.

\section{References}

[1] X. Yin, J. Zhang, and X. Wang, "Sequential injection analysis system for the determination of arsenic by hydride generation atomic absorption spectrometry," Fenxi Huaxue, vol. 32, no. 10, pp. 1365-1367, 2004.

[2] R. S. Blissett and N. A. Rowson, "A review of the multicomponent utilisation of coal fly ash," Fuel, vol. 97, pp. 1-23, 2012.

[3] Z. T. Ahmed and D. W. Hand, "Direct adsorption isotherms of AEAs and fly ash: ??-olefin sulfonate and combination admixtures," ACS Sustain. Chem. Eng., vol. 3, no. 2, pp. 216223, 2015.

[4] A. A. Ramezanianpour, Fly ash, vol. 39, no. 7. Heidelberg, 2005.

[5] N. Koshy and D. N. Singh, "Fly ash zeolites for water treatment applications," Journal of Environmental Chemical Engineering, vol. 4, no. 2. Elsevier Ltd, pp. 1460-1472, 01Jun-2016.

[6] C. Y. Pathak, D. Roy, and S. Das, "Utilization of fly ash byproduct in synthetic zeolites," World J. Civ. Eng. Constr. Technol., vol. 1, no. 1, pp. 2-11, 2014.

[7] G. Itskos, A. Koutsianos, N. Koukouzas, and C. Vasilatos, "Zeolite development from fly ash and utilization in lignite mine-water treatment," Int. J. Miner. Process., vol. 139, pp. 43-50, Jun. 2015.
[8] Z. Liu, S. Li, L. Li, J. Wang, Y. Zhou, and D. Wang, "One-step high efficiency crystallization of zeolite A from ultra-fine circulating fluidized bed fly ash by hydrothermal synthesis method," Fuel, vol. 257, p. 116043, Dec. 2019.

[9] M. Liu, L. A. Hou, B. Xi, Y. Zhao, and X. Xia, "Synthesis, characterization, and mercury adsorption properties of hybrid mesoporous aluminosilicate sieve prepared with fly ash," Appl. Surf. Sci., vol. 273, pp. 706-716, 2013.

[10] P. Whittaker, "Iron and zinc interactions in humans," in American Journal of Clinical Nutrition, 1998, vol. 68, no. 2 SUPPL., pp. 442-446.

[11] H. Figueiredo and C. Quintelas, "Tailored zeolites for the removal of metal oxyanions: Overcoming intrinsic limitations of zeolites," J. Hazard. Mater, vol. 274, pp. 287-299, 2014.

[12] M. Mahurpawar, "Effects of heavy metals on human health," Int. J. Res., vol. 2350, no. 0530, pp. 1-7, 2015.

[13] M. S. Suliman, S. I. B. Yasin, and M. S. A. Eltoum, "Petroleum Coke Carbon, Characterization and Environmental Application," J. Middle East North Africa Sci., vol. 2, no. 4, pp. 10-14, 2016.

[14] D. Ruen-ngam, D. Rungsuk, R. Apiratikul, and P. Pavasant, "Zeolite formation from coal fly ash and its adsorption potential," J. Air Waste Manag. Assoc., vol. 59, no. 10, pp. 1140-1147, 2009.

[15] A. H. Englert and J. Rubio, "Characterization and environmental application of a Chilean natural zeolite," vol. 75, pp. 21-29, 2005.

[16] H. Asnaoui, A. Laaziri, and M. Khalis, "Study of the kinetics and the adsorption isotherm of cadmium (II) from aqueous solution using green algae (Ulva lactuca) biomass," Water Sci. Technol., vol. 72, no. 9, pp. 1505-1515, 2015.

[17] E. Ajenifuja, J. A. Ajao, and E. O. B. Ajayi, "Equilibrium adsorption isotherm studies of $\mathrm{Cu}$ (II) and Co (II) in high concentration aqueous solutions on $\mathrm{Ag}^{-\mathrm{TiO}_{2}}$-modified kaolinite ceramic adsorbents," Appl. Water Sci., vol. 7, no. 5, pp. 2279-2286, 2017.

[18] N. Ayawei, A. N. Ebelegi, and D. Wankasi, "Modelling and Interpretation of Adsorption Isotherms," J. Chem., vol. 2017, 2017.

[19] M. Wdowin, "Synthesis and characterization of zeolites prepared from industrial fly ash," Env. Monit Assess, no. 186, pp. 5721-5729, 2014.

[20] A. Julbe, M. Drobek, I. Européen, and U. De, "Encyclopedia of Membranes," Encycl. Membr., 2016.

[21] K. S. W. SING, D. H. EVERETT, R. A. W. HAUL., J. ROUQUEROL., and T. SIEMIENIEWSKA., "REPORTING PHYSISORPTION DATA FOR GAS/SOLID SYSTEMS with Special Reference to the Determination of Surface Area and Porosity," Pure App!. Chem, vol. 57, no. 4, pp. 603-619, 1985. 
[22] S. Wacharasindhu, S. Likitmaskul, L. Punnakanta, K. Chaichanwatanakul, K. Angsusingha, and C. Tuchinda, "Serum IGF-I and IGFBP-3 Levels for Normal Thai Children and their Usefulness in Clinical Practice," J. Med. Assoc. Thail., vol. 81, no. 6, pp. 420-430, 1998.

[23] K. Pyrgaki, P. Messini, and V. Zotiadis, "Adsorption of Pb and
$\mathrm{Cu}$ from Aqueous Solutions by Raw and Heat-Treated Attapulgite Clay," Geosciences, vol. 8, no. 5, p. 157, 2018.

[24] K. Parida, K. G. Mishra, and S. K. Dash, "Adsorption of toxic metal ion $\mathrm{Cr}$ (VI) from aqueous state by $\mathrm{TiO}_{2}-\mathrm{MCM}-41$ : Equilibrium and kinetic studies," J. Hazard. Mater., vol. 241242, pp. 395-403, 2012. 